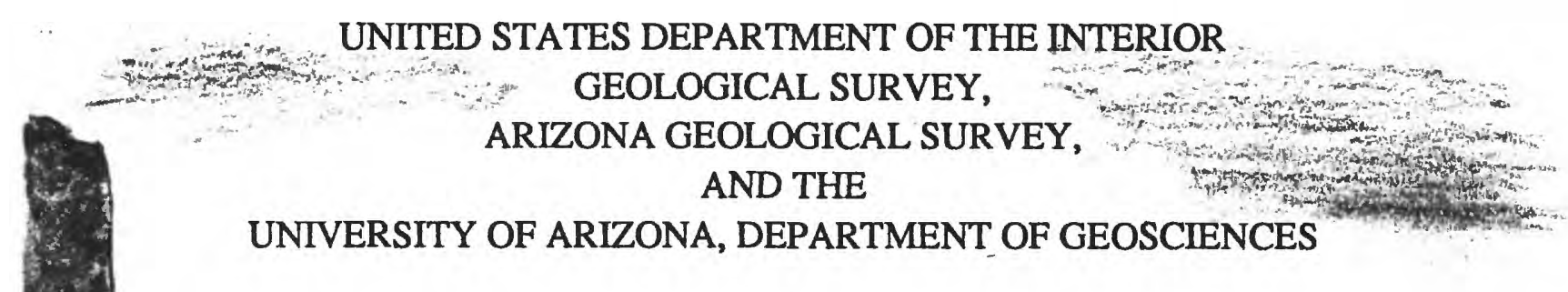

\title{
SUMMARY OF A WORKSHOP ON THE SEARCH FOR UNCONVENTIONAL ORE DEPOSITS IN ARIZONA
}

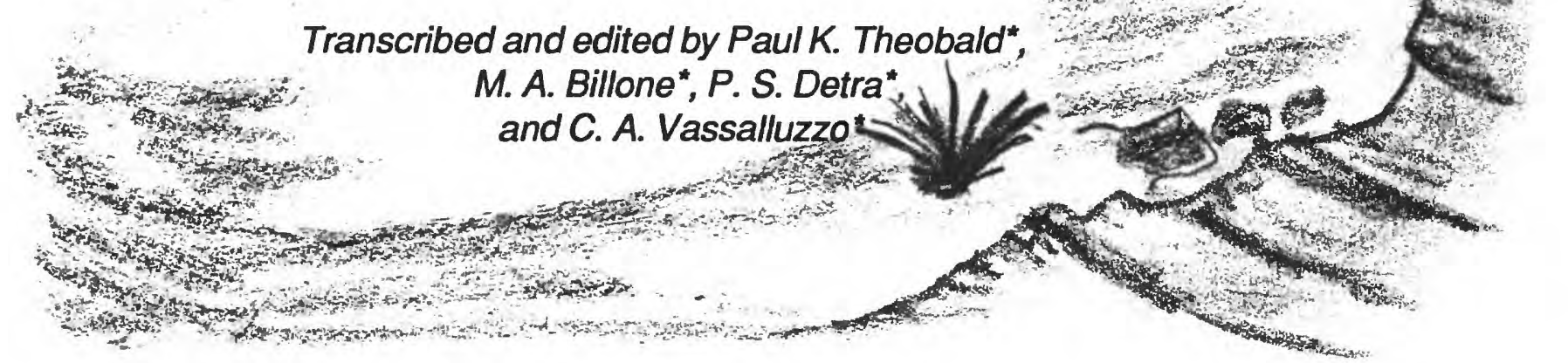

\section{OPEN-FILE REPORT 87-498}

This report is preliminary and has not been reviewed for conformity with U.S. Geological Survey editorial standards and stratigraphic nomenclature. Any use of trade names is for descriptive purposes only and does not imply endorsement by the USGS.

*U.S. Geological Survey, DFC, Box 25046, MS 973, Denver, CO 80225 


\section{CONTENTS}

Page

Introduction

1

Mineral Deposits Associated with Core Complexes, Detachment Faults, and

Related Phenomena ................................................................................................... 2

Mineral Deposits Associated with Calderas, Cauldrons, and Subvolcanic Environments ...................... 4

Mineral Deposits Associated with Peraluminous and Peralkaline Granites and Rhyolites ...................... 6

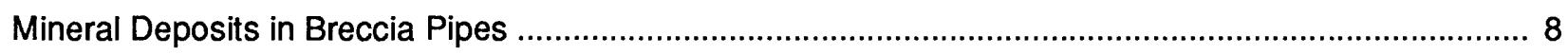

Disseminated Precious Metals in Volcanic and Sedimentary Rocks ................................................ 10

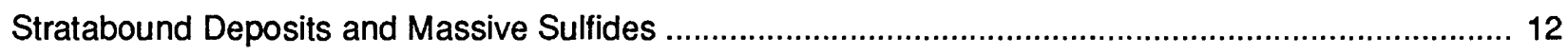

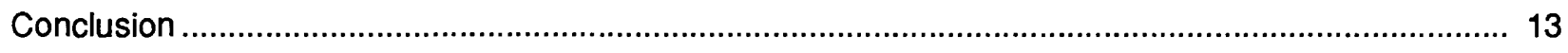

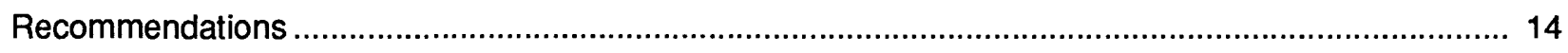

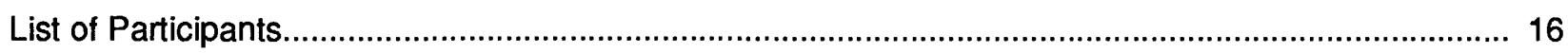




\section{INTRODUCTION}

A workshop on the future of research on mineral resources in Arizona was held on January 12 and 13, 1987, in Tucson, Arizona. The objective was to exchange information from research on the geology of metallic mineral resources. The emphasis was on the potential for the discovery of new ore deposits and on the type of research necessary to fulfill that potential. We recognized at the outset that copper and associated metals derived from porphyry-type deposits related to calc-alkaline igneous rocks have dominated and most likely will continue to dominate metallic mineral production in Arizona. We also recognized that a large research effort has been devoted and will continue to be devoted to the understanding of these traditional deposits. As a result, the potential for other deposit types has largely been neglected. The decision was made to emphasize those geologic environments in which "nontraditional" deposits might be found. The term "unconventional" used in the workshop title simply means "nonporphyry copper deposits."

The workshop discussions centered around six preselected geologic environments with known mineral potential either in Arizona or in adjacent states. These six topics were originally stated to be:

1. Core complexes and detachment faults;

2. Calderas, cauldrons, and subvolcanic environments;

3. Peraluminous and peralkaline granites and rhyolites;

4. Breccia pipes--collapse, diatreme, hydrothermal;

5. Disseminated precious metals in volcanic and sedimentary rocks; and

6. Stratabound deposits and paleoplacers.

As the discussions evolved, it became apparent that these titles were not necessarily appropriate and that the topics overlapped, which is reflected in the summaries that follow. The discussions were intentionally kept informal to stimulate the spontaneous exchange of ideas among the participants. No formal presentations were requested, nor were the proceedings recorded verbatim. Each of the six sessions is summarized herein, based upon notes taken during the sessions.

Two open sessions at the end of each day were directed toward: (1)identifying more general problems of the ore-deposit geology of Arizona and (2) developing the descriptions of areas of research likely to further the understanding of ore deposits in Arizona. The general results of these discussions are summarized in the last two sections of this report under the titles of "Discussion" and "Recommendations."

The workshop was organized by the Arizona Geological Survey, the University of Arizona, and the Office of Mineral Resources of the U.S. Geological Survey. Participants, all of whom contributed to the material presented herein, represented the three state universities, the State Geological Survey, and companion state agencies dealing with mineral resource issues, all facets of the Office of Mineral Resources, and a selection of other federal agencies involved with mineral resources in Arizona. The nongovernmental sector was represented by a single contributor from the Arizona Geological Society. This was a lopsided representation designed primarily to keep the size of the group small enough for open discussion. The list of participants is appended.

The success of the workshop is reflected by the general request that it be repeated in the future, and that a parallel workshop on nonmetallic minerals be considered in the near future. The major purpose of this report is to encourage further discussions. 


\title{
MINERAL DEPOSITS ASSOCIATED WITH CORE COMPLEXES, DETACHMENT FAULTS, AND RELATED PHENOMENA
}

\author{
Described by J. E. Spencer, Joe Wilkins, and E. H. DeWitt \\ Moderated by L. D. Fellows
}

Detachment terranes are known from British Columbia to Sonora. They lie within a fairly narrow belt extending southward from British Columbia, through eastern Washington, Idaho, along the Nevada-Utah border, to the common corner of Nevada, Arizona, and California. More than 10 such terranes are known in southern and western Arizona. All show evidence of Tertiary deformation and, in Arizona, the dated events related to detachment faulting and mylonitization are mid-Tertiary.

The type of terrane consists of an uplifted, mylonitized core flanked by a faulted basin filled by synfaulting sediments. Low-angle normal faults of the uplifted block merge into mylonites; therefore, the brittle fracture to ductile deformation boundary must have been intersected by the master fault. The master fault is considered to be the surface along which a slab of the crust, the lower plate, was displaced up and out from beneath the basin during crustal extension. Release of the confining weight of the upper plate led to isostatic uplift and warping of the lower plate, further lowering the dip of the fault and eventually exposing the fault and the lower plate at the surface. The upper plate is shattered along a series of normal faults that flatten with depth and merge into the master detachment fault (listric faults). The basin, formed on the displaced upper plate, traps sediment, sand, silt, and gravel from the uplift and from adjacent uplands. Early sediments are caught up in the faulting as detachment faulting continues and later sediments continue to bury the upper plate.

The whole process is in response to crustal extension. The core complex, the uplifted segment of the lower plate, represents deep-seated rocks transported to the surface during a period of several million years. The effect is to compress the thermal gradient as these originally deep rocks are juxtaposed against rocks of much shallower origin or exposed at the surface. Limited information on fluid inclusions allows an estimate of temperatures of the order of $100^{\circ} \mathrm{C}$ to $300^{\circ} \mathrm{C}$ along the detachment surface. These temperatures decrease rapidly into the upper plate. Isotopic equilibration of selected minerals tends to verify these maximum temperatures, to establish the time of cooling through several temperature equilibration points, and in some instances to establish the age of crystallization of the parent rocks in the core complex. Assuming there are reasonable thermal gradients at the few localities adequately studied, a maximum of 8 to $10 \mathrm{~km}$ seems likely for the pre-uplift depth of the rocks now exposed in the core. Higher thermal gradients, or additional heat sources, would reduce these depth figures.

Maximum temperatures in the exposed parts of the detachment system were not adequate to initiate partial melting. There seems to be a general lack of Tertiary igneous activity associated with the detachment systems at the present level of exposure, which supports the apparent lack of evidence for melting and rules against at least one external heat source.

The mylonite varies from a few tens of meters to as much as $4 \mathrm{~km}$ in thickness. A breccia zone is virtually ubiquitous near its upper surface. The mylonite itself is largely the result of tectonic shearing of the rocks at temperatures sufficiently high for quartz to behave ductiley. In contrast, the breccias, particularly those in the lower plate, have been pervasively altered to chlorite (chloritic breccias). Enormous volumes of rocks in the upper plate have been affected by potassium metasomatism, possibly releasing copper, iron, and manganese. There is no evidence for sodium metasomatism. The extensive brecciation associated with brittle deformation of the upper plate provided important avenues for the 
migration of fluids. Whether there was extensive exchange of fluids across the mylonite zones is not clear.

Direct measurement of fluid characteristics is difficult. Fluid inclusions are rare and small. Even the most suitable host mineral, quartz, is hard to find. The few inclusions that can be found contain two phases, liquid and gas, occasionally with daughter products of petroleum. No evidence of $\mathrm{CO}_{2}$ or of boiling has been found. All have high salinities that are independent of temperature. Fluids in the lower plate were evidently reducing, whereas those of the upper plate were oxidizing.

Alteration and mineralization were contemporaneous with faulting. Although large volumes of rock in the lower plate are altered, most of the mineralization is in the upper plate. Major deposits are of manganese, iron, or copper; minor deposits are of lead and zinc, uranium, silver, or gold. Alteration and gangue minerals reflect redistribution or introduction of barium, fluorine, silver, potash, and carbonate. Early formed sulfides near the detachment--pyrite and chalcopyrite--are replaced, in time and with distance upward into the upper plate, by oxides. The predominant ore mineral, hematite, is deposited near the detachment fault or replaces reactive calcareous units in the upper plate near the fault. The detachment fault is not planar, and the favored site for mineralization near the fault is along large synforms on the detachment surface. The loci for ore deposition are: (1) the detachment fault zone, (2) reactive units in the upper plate (replacement ores in calcareous rocks), (3) fault breccias of the listric normal faults, (4) gash veins, (5) longitudinal veins along fault axes, and (6) the chlorite breccia. In the upper plate, copper occurs as primary copper carbonates. Base and precious metals are deposited higher in the upper plate, and the large manganese deposits, such as those in the Artillery District, are the highest in the sequence.

Establishing the synchronism of faulting and mineralization is difficult. The relationships are reasonably well established for the Whipple, Rawhide, Buckskin, and Harcuvar Mountains along the Arizona-California border. Some deposits in the lower plate have Cretaceous ages, thus predating the detachment fault. For these deposits, the spatial association with the detachment fault is fortuitous. Particularly problematic in this regard is the spatial association of the gold deposits in southeastern California and southwestern Arizona with low-angle detachment faults.

The general framework of detachment terranes and the mineral deposits associated with them is readily outlined, but major unanswered questions remain. The origin and mechanics of detachment faulting is not known; nor is the mechanism of normal fault propagation well understood. The thoroughly scrambled and recrystallized rocks of the lower plate will require careful and sophisticated examination to determine the parentage, source, and evolution of the core complex. The nature of the upper plate, thoroughly dismembered and largely buried by detachment-age sediments in the basin, is poorly known. The source and migration paths of the fluids responsible for the extensive alteration and mineralization are controversial. Convection in the developing basin could provide oxidized fluids of both high and low salinity. Extensive study of mineral paragenesis, both in altered rocks and the mineral deposits, is needed. More control on the timing of mineralization relative to the evolution of the detachment system is required, if for no other reason than to decide which deposits are detachment related and which are not. Many of these remaining problems are best addressed in the basins, where remote and indirect techniques such as geophysics, vapor geochemistry, and eventually drilling will be required. 


\title{
MINERAL DEPOSITS ASSOCIATED WITH CALDERAS, CAULDRONS, AND SUBVOLCANIC ENVIRONMENTS
}

\author{
Described by M. F. Sheridan and J. Ruiz \\ Moderated by W. R. Dickinson
}

This session shared common ground with the sessions on peraluminous granites, peralkaline granites, and rhyolites, and on disseminated precious metals in volcanic and sedimentary rocks. Numerous calderas are documented in New Mexico, Nevada, southern California, and Mexico. Approximately 50 calderas in Nevada have been related to economic mineral deposits, and there are about 20 calderas in the Mogollon volcanic field of New Mexico alone. Only three calderas or caldera clusters have been documented in Arizona. In the western U.S., 550 major ash flows have been identified, but only about 250 calderas are known. Although a caldera may yield more than one flow, there are apparently many calderas or their deep counterparts yet to be found. From this purely statistical point of view, Arizona is prime country for the search for, and study of, calderas.

Calderas are the product of eruption of large volumes of rhyolitic magma from a central vent. The explosive volcanism produces a crater of its own and, in the typical model, the evacuation of the shallow magma chamber by the eruption leads to collapse in the vent area, greatly enlarging the caldera. The crater is filled by collapse breccias of country rock as well as by the variety of rhyolitic volcanic products. Subsequent injections of magma may dome the caldera floor and extrude rhyolite domes along the fractured perimeter of the caldera.

A typical section of a caldera includes an outer scarp formed by erosional retreat from the crudely circular ring fracture marking the outer limit of collapse. The ring fracture itself is a site of subsequent magma intrusion, the extrusion of domes, and the accumulation of collapse breccias. Resurgence leads to uplift of the central part of the caldera floor and to the intrusion and extrusion of additional material.

Calderas vary in size; a large caldera can be $50 \mathrm{~km}$ in diameter but they are more commonly 10 to $30 \mathrm{~km}$ in diameter.

The ash flows and tuffs discharged at the surface during the eruption are mobile and spread for large distances outward from the crater. These lateral deposits are relatively thin. Within the caldera, fall-back and trapped pyroclastic material can accumulate to thicknesses from $500 \mathrm{~m}$ to single pyroclastic deposits as much as 2 to $3 \mathrm{~km}$ thick. The thickness of these deposits may provide a valuable clue in the search for calderas--the thicker they are, the closer is the source caldera, and exceptional thicknesses are expected to be only within the caldera.

Collapse breccias within a caldera consist of a mixture of pre-volcanic country rocks, volcanic rocks of earlier cycles, and juvenile volcanic material. The breccia fragments range from sand-sized material to huge blocks. One block $2 \mathrm{~km}$ long and 500 to $700 \mathrm{~m}$ thick has been reported.

Caldera formation can deviate from the simple explosive volcanism-collapse-resurgence model. Deeper calderas may collapse in bits and pieces, and dike and sill systems may predominate over surface volcanic ash. Asymmetric collapse is common and leads to the formation of low-angle faults. Collapse may be of the trap-door type, where the ring fracture does not propagate around the entire collapsing block but leaves an attached hinge at one side. Collapse need not be directly related in space with the explosive volcanism. For example, although $15 \mathrm{~km}^{3}$ of material was erupted from the caldera at 
Katmai, and a part of a mountain slid into the vent, the caldera itself did not collapse. Some $10 \mathrm{~km}$ away from the caldera, Mount Katmai collapsed at the time of eruption.

Most of the calderas that have been identified in the western U.S. are middle Tertiary or younger in age. In part this is because the younger features are less deformed, better preserved, and hence more easily recognized. In part this reflects a change in the magmatic evolution in the region. Igneous rocks of Mesozoic and early Tertiary age are primarily intermediate in composition. Volcanic piles are largely of andesitic composition. Beginning in the middle Tertiary, these compositions gave way to a bimodal assemblage of basalt and rhyolite. Thus, the more explosive volcanism associated with rhyolitic magmas likely led to the formation of more calderas in the late Tertiary. A variety of mechanisms has been considered to explain the change in the composition of the volcanic rocks. A current theory suggests that two separate magmas are involved. Melting of the mantle produces a basalt that invades the crust at a high temperature. Cooling of this layer of basalt transfers heat to the wall rocks and thus melts crustal rocks of granitic composition to produce a less-dense magma with greater potential for migration upward through the crust than the basalt.

Late Tertiary terranes may not be the only targets for calderas; older calderas tend to be highly deformed by later events and eroded to deeper levels. They are therefore less easily recognized. Recent geologic reinterpretation suggests the presence of Laramide-aged calderas in several areas, such as at Silver Bell and in the Bagdad district. Thick stacks of welded tuffs in the Jurassic rocks of the Southwest need to be interpreted with an eye to identifying calderas. Extensive terranes of rhyolite in the Precambrian may also have calderas.

Calderas provide favorable environments for ore deposits. The rocks are highly fractured and permeable breccias are abundant. A large, near-surface heat source is available in the shallow magma chamber, and the magmas are often enriched in the volatile elements as well as some of the ore elements. Large convection cells for the circulation of ground water can develop and can be maintained for considerable periods of time. The cycling ground water can strip metals from the country rocks as well as the igneous rocks. Interaction of circulating water with the hot magmatic rocks can lead to phreatic explosions and hydrothermal brecciation, which further opens the system for continued circulation of hydrothermal fluids.

The most obvious examples of this hydrothermal activity are active geothermal systems, such as the Taupo area of New Zealand, where active, metal-rich hydrothermal systems provide a contemporary model. Numerous epithermal precious-metal deposits are associated with resurgent domes, with the ring-fracture systems and low-angle faults in the collapsed block, and with hot-spring activity around the caldera rim. At depth, base-metal deposits may occur in the ring fracture or be in hydrofractured roofs of the shallow magma chamber. The explosive volcanism may, however, destroy earlier mineral deposits. Tin, tungsten, and beryllium may be enriched in some caldera-related rhyolites.

Calderas provide excellent sites for the accumulation of ore deposits, but the source of the metals remains uncertain. Both a juvenile magmatic source and a source in the host rocks have been invoked in genetic models. Combinations of trace-element and stable and radiogenic isotopes in ore minerals, parent magmatic rocks, and country rocks offer potential for identifying metal sources. Fluorite is a common ore or gangue mineral in deposits related to caldera-forming rhyolites. The abundance of strontium, its isotopic composition, and the abundance and relative abundances of the rare-earth elements are particularly useful for tracing the possible sources for the calcium in fluorite. In some deposits that have been studied, most of the strontium and rare-earth elements were derived from host limestones; in others, most were derived from the ore-related igneous rocks. In some instances, the composition of the fluorite in the ore falls on a mixing line between the igneous rock and the host rock. In these instances, the relative contribution from the two sources may be estimated. At present, techniques 
of this sort are largely empirical. For more quantitative modeling, experimentally derived distribution coefficients among the various minerals and fluids will be needed.

Our knowledge of the relationship of ore deposits to calderas in Arizona is limited by the few calderas that have been identified in the state. This may reflect the lack of work on middle Tertiary and younger volcanic rocks. New mapping is needed, as is the reinterpretation of geologic relationships in areas with thick stacks of welded tuffs. Geophysical data, particularly gravity data, may aid in locating potential calderas, based on the assumption that calderas are associated with large volumes of low-density material. Electrical geophysics can assist geological studies by defining the thicknesses of less-resistive volcanic rocks, which may contrast with a more resistive basement. The identification of older calderas using traditional criteria is confounded by subsequent structural disruption, metamorphism, and erosion. When calderas are located, considerably more detailed mapping and stratigraphy are required to define the favorable environments within the calderas. Considerable emphasis on petrology, geochemistry, and petrogenesis is needed to establish the genesis and evolutionary trends of ore deposition and to determine the controls on devolatilization, brecciation, and the evolution and migration of hydrothermal fluids.

\title{
MINERAL DEPOSITS ASSOCIATED WITH PERALUMINOUS AND PERALKALINE GRANITES AND RHYOLITES
}

\author{
Described by D. M. Burt, J. M. Guilbert, G. B. Haxel, \\ C. M. Conway, and W. I. Ridley \\ Moderated by G. H. Allcott
}

A semantic problem was evident from the start of this discussion. The variety of terms used included peraluminous or peralkaline granites, two-mica and two-mica garnet granites, anorogenic granites, high-silica granites and rhyolites, tin rhyolites, and topaz or high-fluorine rhyolites. The most common thread seems to be that these granites and hyolites differ from the more common, "normal," calc-alkaline, biotite-hornblende series of igneous rocks. For convenience, we will limit these terms to (1) two-mica granites and (2) the high-silica rhyolites, realizing that one of the problems to be resolved is the real nature of the categories.

The two-mica granites are abundant in the Basin and Range Province from British Columbia to Sonora. A couple of dozen plutons are known in southern and western Arizona. The high-silica rhyolites have a similar but more restricted distribution. In the Basin and Range Province, the rhyolites are most common in the eastern part of the Province close to the Colorado Plateau. They are also common along the Rio Grande Rift in New Mexico and Colorado. Topaz-bearing rhyolites are known only at two localities in Arizona, though a more thorough search is expected to reveal others.

Most granites in western North America are Cretaceous to early Tertiary in age. In Arizona, most granites are early Tertiary in age, but others are Precambrian, having 1.7, 1.4, and 1.1 b.y. ages. The topaz rhyolites yield younger ages in the range of 50 to 0.5 m.y. (middle Tertiary to Quaternary).

The magmas that gave rise to the two-mica granites and the high-silica rhyolites are generally thought to result from the melting of continental crust. The close proximity in time and space of the two-mica granites and the calc-alkaline plutonic rocks suggests melting at different levels in the crust or in a heterogeneous crust. The calc-alkaline granitoids probably contain a mantle component. The suggestion that the two-mica granites are derived from sedimentary rocks seems to be contradictory on the basis of strontium and oxygen isotopic data. 
The designations as peraluminous and as peralkaline were challenged in many instances. The strict limitation of peraluminous to rocks with molecular $\mathrm{Al}_{2} \mathrm{O}_{3}$ in excess of $\mathrm{K}_{2} \mathrm{O}$ plus $\mathrm{Na}_{2} \mathrm{O}$ plus $\mathrm{CaO}$ resulted in ambiguous definitions for many of the high-silica rocks described; their compositions often straddled the boundary between metaluminous and peraluminous. Restriction of peralkaline to rocks with molecular $\mathrm{Na}_{2} \mathrm{O}$ plus $\mathrm{K}_{2} \mathrm{O}$ in excess of $\mathrm{Al}_{2} \mathrm{O}_{3}$ yielded a similar ambiguity. Nevertheless, the propensity for these rocks to differentiate, yielding end members extremely enriched in a number of lithophile elements, was recognized. A mechanism of in-situ differentiation was proposed wherein residual liquid in the crystallizing mass separates and moves laterally and upward toward the apex of the intrusion. Unlike the traditional crystal-settling model, this mechanism could produce highly evolved differentiates relatively early in the crystallization history.

The character of the products of magmatism changes with depth of emplacement. At depth, the magmatic differentiation products are less well separated and the extreme products take the form of pegmatites and veins. At intermediate depth, a complex of extreme differentiates can accumulate in the roofs of cupolas, and hydrofracturing can allow formation of vein dikes and stockwork veining.

Greisenization and wall-rock reaction or replacement occur. Emplacement near the surface often leads to explosive volcanism at the surface with extrusion of high-silica rhyolites in domes, ash flows and falls, and a variety of coarse volcaniclastic deposits.

The characteristics that distinguish these igneous rocks from the "normal" igneous rocks include (1) the presence of primary muscovite, (2) occasionally modal corundum, (3) commonly normative corundum, (4) topaz and/or fluorite, (5) high silica in differentiates (often $75 \%$ or greater), (6) sometimes high alkalies, (7) strong negative europium anomalies in the rare-earth-element patterns, (8) often a concave-upward rare-earth pattern, (9) high initial strontium isotopic ratios, (10) negative e neodymium, and (11) enrichment in several of a characteristic suite of trace elements including $\mathrm{Nb}, \mathrm{Ta}, \mathrm{Sn}, \mathrm{Be}, \mathrm{Rb}$, $\mathrm{Cs}, \mathrm{Th}, \mathrm{U}, \mathrm{Mo}$, and $\mathrm{W}$. Not all of these characteristics apply to any individual pluton. In fact, reversals of some of the characteristics are common. For example, differentiation can lead to an aluminum-rich, alkalic-poor pluton paired with an alkalic-rich, aluminum-poor pluton. Whereas many of the plutons are halogen rich, particularly in fluorine, others are halogen poor. Among the trace elements, niobium, tantalum, tin, and beryllium are the most frequently enriched, whereas molybdenum and tungsten may or may not be enriched.

Mineral deposits associated with these rocks reflect a characteristic suite of trace elements, which includes many of the strategic and critical metals for the U.S. Primary deposits are found above and along the upper flanks of cupolas. The physical form of the primary deposits reflects the level of intrusion: pegmatites at greatest depth; veins, greisens, and stockworks at intermediate depth; and mineralized flows or volcaniclastic rocks near vents at the surface. Included among the deposits in the southwestern U.S. are the rare-metal pegmatites in New Mexico, the porphyry molybdenum deposits of Colorado and Utah, the beryllium deposits in rhyolite in Utah, and the tin deposits in rhyolite in New Mexico.

In addition to the primary deposits, a variety of secondary deposits can be formed by redistribution of elements or minerals from the granites and rhyolites. Leaching of uranium from the rhyolites and redeposition in reactive rocks below the rhyolites can enrich the uranium to ore grade. Leaching of lithium, in particular, and entrapment in ground water of closed basins can yield lithium brines. Selective weathering, erosion, and transportation of minerals from the plutons, too low in grade to be of interest by themselves, have produced many of the major placer deposits of the rare metals. 
In addition to the metals, gems are recovered both from the pegmatites and from miarolitic cavities in the rhyolites. Fluorite deposits occur as veins and as replacement deposits in carbonate rocks.

Considerably more geochemical work is needed to provide a better classification of the two-mica granites. With this in hand, trace-element and isotopic studies have a fair chance of characterizing differentiation trends and identifying those intrusive systems that may have yielded potential ore-forming systems. As with the calderas, it seems likely from regional consideration that more of the high-silica rhyolites are to be found in Arizona. Because of the relatively high concentration of radioactive elements in these rocks, the evaluation of aeroradioactivity maps may provide early regional discrimination of areas deserving priority. The location and geochemical characterization of these rhyolites should provide clues to potential resources. Similar arguments apply to the distribution of pegmatites. It does not seem reasonable that the cluster of pegmatites north of Phoenix is the only occurrence in Arizona. The large tungsten-bismuth and molybdenum-rich pegmatite in the central Mohawk Mountains is a candidate, but its age and relation to highly evolved granites are unknown. Within the critical suite of elements associated with the two-mica granites and the high-silica rhyolites, tin stands out as an element commonly encountered in quantities suggesting resource potential. There is at present no systematic evaluation of the distribution and geochemistry of tin in Arizona that is adequate to provide the basis for both lode and placer resource evaluation. Few people would be surprised if a significant tin occurrence were found in the state.

\title{
MINERAL DEPOSITS IN BRECCIA PIPES
}

\author{
Described by K. J. Wenrich, D. P. Cox, and D. P. Klein \\ Moderated by L. D. Fellows
}

The discussion of mineralized breccia pipes was confined to collapse breccias. In contrast with calderas, there are many known breccia pipes in Arizona. Many hundreds have been identified on the Colorado Plateau in northwestern Arizona. The few known elsewhere in the world may include Ruby Creek in the Brooks Range, Alaska; Kipushi, Zaire; Tsumeb, Namibia; and, in particular, the Apex mine in the Basin and Range Province of Utah.

The breccias on the Colorado Plateau are hosted by nearly horizontal, little-distorted, late Paleozoic to early Mesozoic strata. None are known to extend below the Redwall Limestone of Mississippian age or above the Chinle formation of Triassic age. The breccias consist of fragments of the host rocks, all of which have moved downward into the structure. Over the tops of the breccia pipes, strata sometimes dip inward toward the pipes, and on the plateau surface the pipes are most readily recognized as shallow, circular depressions. A nearly circular, nearly vertical, ring fracture 200 to $500 \mathrm{~m}$ in diameter separates the pipes from adjacent, undeformed wall rocks.

The pipes were evidently initiated by extensive karst development that probably formed an extensive cavern system in the Redwall Limestone. Continued solution of carbonate cement by downward percolating water and simple collapse of overlying strata allowed propagation of the structure upward, and subsequent filling of the resultant pipe. The process evidently continued, at least intermittently, from the Mississippian through the Triassic, and apparently was terminated in the Triassic, because no disruption of Jurassic or younger strata has been found. Karst development was also active following deposition of the Permian carbonates, above which shallow breccia pipes occur. The clustering and alignment of pipes are interpreted to reflect cave development in the carbonates that may be structurally controlled. 
All of the presently known mineralization is in pipes that extend downward to the Redwall Limestone. None of the shallower collapse features that have been tested by drilling are mineralized. Dolomitization is extensive in mineralized pipes, and a bleached zone caused by changes in the oxidation state of iron surrounds mineralized pipes in favorable wall rocks. A few pipes are silicified, but the silicification is not thought to be related to metallization. Thus, alteration is a poor guide to mineralization. The major surficial indications for mineralization are the presence of abundant iron oxides, traces of secondary copper minerals, particularly near the ring fracture, and abnormal radioactivity. These criteria are useless for blind pipes that did not stope high enough to breach the present surface.

The principal ore metal of the breccia pipes, historically, has been copper, usually with silver. More recently the pipes in Arizona have been mined solely for uranium. The Apex mine, originally a high-grade copper deposit, is now mined for germanium and gallium contained in jarosite and goethite. Lead, zinc, cobalt, and nickel have also been recovered.

The primary ore minerals are sulfides. Pyrite is predominant and may provide a cap to ore. Copper occurs predominantly as chalcopyrite or chalcocite. A variety of other metal sulfides and arsenic sulfides are locally present. The systems are arsenic rich. Galena and sphalerite are common. Most uraninite, the common uranium mineral, is distinctly later than the sulfides. Pyrite may have served as the reductant to initiate uranium precipitation. Gold is enriched in a few pipes where it is invariably associated with zinc in hemimorphite in the oxidized zone. Both the trace-element assemblage and the mineralogy have marked similarity to Mississippi Valley-type deposits; however, the high-grade uranium ore $\left(1.0 \% \mathrm{U}_{3} \mathrm{O}_{8}\right.$ average for many of the pipes) is unique to the Colorado Plateau and the high-grade germanium and gallium (600 ppm and 300 ppm, respectively) are unique to the Apex mine.

The pipes were produced by downward percolating solutions, whereas the ore minerals were deposited from ascending solutions. Thus the mineralization completely postdates formation of the pipes. The most likely age of mineralization on the Plateau is about 200 m.y., near the Jurassic-Triassic boundary. A model can be constructed for uplift of the edge of the Plateau at about this time, producing a highland to the south that provided the necessary hydraulic head. Ground water descending from the highland in a confined aquifer in the Redwall Limestone could escape upward through the pipes.

The mineralizing fluids were relatively cool, in the general range of $80^{\circ} \mathrm{C}$ to $170^{\circ} \mathrm{C}$, again similar to Mississippi Valley-type deposits. The indicated temperatures are greater than would be expected from present geothermal gradients on the Colorado Plateau. Fluid-inclusion salinities are high, commonly greater than 20 wt. percent $\mathrm{NaCl}$ equivalent in sphalerite, calcite, and dolomite.

Photogeologic techniques have been highly successful in locating circular depressions related to pipes in areas of sparse vegetation. Geophysical techniques offer considerable potential for locating pipes in forested areas and for sorting the promising surface features to determine which are deeply rooted and mineralized breccia pipes. Where structural control of the cavern system initiating pipe formation is evident, careful analysis of aeromagnetic data may be useful. The aeromagnetic interpretation yields information on the basic structural fabric, not on the location of individual pipes.

On the ground, audiomagnetotelluric surveys over 15 pipes have provided a direct measure of the geometry, depth, and continuity of the altered and mineralized zones associated with pipes. The vertical plug of low resistivity coincides precisely with the pipe configuration as shown by drill information. If the relationships obtained in these tests hold up, the method will provide a powerful tool for sorting among suspect structures to determine which are breccia pipes and to determine which pipes are initiated in the Redwall Limestone and which pipes originate higher in the stratigraphic sequence. The observed resistivities are too low to be accounted for solely by mineralization and must reflect the 
presence of adequate moisture in the brecciated and altered rock to produce a conductor. Further, in several blind pipes explored the conductive zone continues almost to the ground surface which suggests that shallower electrical exploration techniques may be used to define mineralized pipes. Telluric traverses provide a rapid means of detecting the zones of low resistivity, but provide little information on the geometry or depth of the pipe. Because of the small size of the low-resistivity target, the electrical techniques so far tested are probably not useful for reconnaissance exploration.

Advances in exploration technology are needed to increase the efficiency of the exploration process. The current practice of drilling on the basis of a few indirect and inconclusive clues is expensive. Research directed at improving this technology is needed in four problem situations: (1) in areas of good surface exposure, mechanisms are needed to sort among suspect structures to determine which are deep-rooted pipes with mineral potential; (2) in areas of poor surface exposure, mechanisms are needed to locate the suspect structures; (3) there is no clear way at present to locate pipes that did not stope to the level of the present surface (blind pipes); and (4) the Apex mine provides direct evidence that the pipes exist in the Basin and Range Province as well as in the Colorado Plateau. The transition zone west and south of the Plateau is a prime candidate for exploration. In this area, disruption of the original characteristics of the pipes makes the search all the more difficult. Advances in geochemistry and particularly in geophysics, coupled with more detailed geology, will allow great progress toward the solution of these problems.

\title{
DISSEMINATED PRECIOUS METALS IN VOLCANIC AND SEDIMENTARY ROCKS
}

\author{
Described by B. R. Berger, S. R. Titley, D. P. Cox, \\ B. D. Smith, and R. L. Earhart \\ Moderated by W. R. Dickinson
}

Worldwide, and in Arizona, gold is found in sedimentary rocks of a great variety of ages. The distribution of gold production with the age of the rocks is not uniform. Three age groups within the Precambrian, the lower Paleozoic, and the upper Cretaceous have provided disproportionately large shares of the gold production. In part, these high spots result from single, large ore deposits. In Arizona, historic production of precious metals is distributed among Precambrian rocks and rocks associated with the Nevadan (minor), Laramide, and mid-to-late Tertiary orogenesis. If by-product gold is excluded, the mid-to-late Tertiary is particularly favorable.

Precambrian deposits are generally associated with exhalites of one type or another, though the location of the deposits also reflects metamorphic grades. Iron formations are good indicators of an appropriate environment. The chemical sediments near the transition from volcanic to sedimentary rocks are particularly favorable. In general, vent areas are more favorable for gold than distal areas, although the identification of vent facies is often difficult in these old rocks. The Precambrian of Arizona consists of several profoundly different terranes. Ore genesis within each of these terranes is completely different. Not only does the nature of the Precambrian terrane control the type of mineralization within it, but the composition of this "basement" influences the nature of mineralization of all ages within the terrane.

Precious-metal mineralization associated with middle and late Tertiary volcanism is currently receiving much attention. Many deposits in this age group have been discovered, or rediscovered, in the last decade in Nevada and southern California. Few are known in Arizona. As with the closely associated calderas, the apparent paucity of precious-metal deposits of this type may result from the lack of emphasis on the study of young volcanics by economic geologists. 
There are numerous models for the Tertiary disseminated gold deposits, and almost as many questions about what they should be called; however, they seem to fall into two general categories on a basis of host lithologies--volcanic hosted and sediment hosted--and into two general categories on a basis of the composition of the ore-forming fluid--alkali chloride and acid sulfate. Most have certain features in common. They cluster along major structural zones, and they occur in near-surface rocks with abundant brecciation or shallow faulting or in reactive rocks. Formation temperatures are fairly low $\left(250^{\circ} \mathrm{C}\right.$ or less), and large quantities of water are involved. Ages of mineralization range from Cretaceous to Holocene.

One model would envisage a magmatic heat source located along a major structural zone. Circulating water from surrounding highlands enters the system, is heated, and driven convectively up the structurally prepared conduit. At depth, relatively high temperatures are involved, and the upwelling plume is fairly narrow. Near the surface, the plume mushrooms into shallow, permeable areas and temperatures drop. Permeability may be increased by hydrothermal explosions, accompanying rapid boiling or degassing, and by alteration. Alternately, permeability may be decreased, or the system plugged, by mineral deposition. Mineralization takes the form of cement in breccias, vein and fracture fillings, or replacement of reactive rocks. The gas-rich systems generally are more auriferous than more pure aqueous systems, even among parts of a single system. The metals are most likely scavenged from the country rocks as the fluids migrate toward the heat source and are deposited in a narrow zone near the top of the upwelling system. Repeated cycles of deposition over a long period of time may be required to produce ore.

Alteration is often intense. Argillic alteration and silicification are common. Quartz-adularia alteration is common in alkali-chloride systems and alunite is common in acid-sulfate systems. Alteration may provide a regional guide to ore; however, the direct relationship of economic mineralization and particular alteration zones is often obscure. Prominent alteration zones may be barren and nearby ore zones may appear less altered. This is particularly perplexing in the sediment-hosted deposits where alteration may be difficult to recognize at all. In areas of intense alunitization, the prospective ore zone may be at considerable depth below the alunite.

The Taupo geothermal zone in New Zealand and the Steamboat Springs geothermal system in Nevada provide modern analogues. The nested, mineralized calderas of the San Juan volcanic field in Colorado and New Mexico provide a well-studied fossil example. Numerous districts in Arizona should be re-evaluated with this model as a guide. In particular, the Patagonia, Oatman, and Tombstone districts have many of the characteristics common to disseminated gold deposits. Re-evaluation of age relationships in the Ajo district leads to the conclusion that the Cornelia quartz monzonite consists of two bodies of markedly different ages separated by the Gibson fault. Whereas the body east of the fault is Laramide as inferred by Gilluly, that to the west of the fault is mid-Tertiary. Thus the root for the porphyry copper deposit is not the pluton west of the fault as previously considered. The spatial association of subeconomic veins with the younger pluton allows speculation on precious-metal potential distinct from the conspicuous copper deposit.

A broader approach to the understanding of the geologic framework of Arizona would also be fruitful for the search for ore deposits, particularly for deposit types such as the disseminated gold deposits that are relative newcomers to the resource scene. A number of data bases are available for the state, including geologic maps, mineral-resource descriptions, aeromagnetic data, gravity data, airbome radiometric data, regional geochemical data, and remote-sensing data. None of these bases are complete with the detail one would desire, and most of them contain flaws; however, they do provide a large base for the examination of the interrelationships of geologic features. The technology is now available to render the various formats of these data bases into a compatible style, thus allowing cross correlations among them. It is an appropriate time to begin putting these data bases together. 
Several research directions that would improve the confidence of the exploration effort for disseminated gold deposits are evident. These range from the exhaustive study of individual deposits (for example, the Mesquite deposit currently defies classification), or mining districts as suggested above, to broader studies of geologic processes. It is clear that the Precambrian of Arizona consists of a number of distinct terranes, and that Precambrian and younger deposits reflect the character of these basement blocks. The location, nature, boundary conditions, and metamorphic history of these terranes are only fragmentally known, even in those areas where the basement is exposed. A concerted effort to understand the basement would be justified. As has been recorded for other discussions, the nature and the centers of mid-Tertiary volcanism in Arizona are poorly known. It seems likely that this volcanism provided the major driving force for the hydrothermal fluids responsible for the disseminated gold deposits. Similarly, the paleogeography and paleohydrology, including refinement of the methods for tracing fluid migration, need to be understood so that the sources for both the fluids and for the metals they accumulate during migration may be predicted.

\title{
STRATABOUND DEPOSITS AND MASSIVE SULFIDES
}

\author{
Described by K. E. Karlstrom and G. R. Robinson, Jr. \\ Moderated by W. R. Dickinson and G. H. Allcott
}

Deposits of several types and ages can be discussed under the general titles of stratabound deposits and massive sulfides. In Arizona, the United Verde, United Verde extension mines near Jerome, and mines in the Bagdad district are examples. These Precambrian deposits are considered to be deformed and metamorphosed examples of the classical exhalite types common in Canada and elsewhere. Also included would be many of the deposits originally attributed to limestone replacement that would now be called carbonate-hosted massive sulfides. These are common in the Paleozoic rocks of Arizona and in the Cretaceous rocks of New Mexico. It is possible that Cenozoic equivalents of the latter are in the basins, both the grabens of the Basin and Range and the half grabens of the detachment systems, in an environment somewhat comparable to rift-type basins.

Major Precambrian deposits appear to be restricted to the Yavapai Series which is apparently divisible into several tectonic blocks, representing different crustal levels that evolved separately from the Proterozoic rocks in southeastern Arizona. The exhalite deposits have general characteristics similar to those already described for disseminated gold deposits. However, the favorable criteria are much more difficult to apply in Arizona because of the complex metamorphic and structural history superimposed on the original ore deposit. During folding, there was considerable movement and redistribution of material with concentration and/or preservation of major sulfide bodies in fold hinge zones. Sulfide deposits on limbs of folds tend to be small boudins and pods. In order to understand the deposits and predict potential for additional discoveries, we will need to understand: (1) the extent and distribution of the ores prior to deformation (Were the exhalites extensive blankets or small, localized deposits?); (2) the regional tectonic setting and present geometry of crustal blocks that contain rocks favorable to host massive sulfides; (3) macroscopic geometry of folds and thrusts and their control on distribution of massive sulfides within individual mining camps; and (4) the effect of metamorphism on redistribution of ore materials.

The general model for the carbonate-hosted massive sulfides is similar in many respects to those that have been discussed with respect to the detachment systems, the breccia pipes, and disseminated gold. It involves a suitable source for saline fluids, a suitable array of permeable conduits to allow transport of the fluid, an energy source to drive the transport of fluids, and a suitable trap for metals. The deposits appear to be related to the transport of metal-bearing brines from tectonically active intracratonic 
basins to shallow sites of sulfide precipitation. Crustal thinning or detachment faulting is commonly invoked to bring hot rocks close to the surface and thereby to provide an abnormally high thermal gradient and an energy source. Connate waters in red bed sequences or evaporites provide a suitable source for saline fluids to dissolve metals. The boundary faults in rift systems, listric faults in detachment systems, and permeable units in the stratigraphic sequences provide suitable conduits for fluid migration, and the deformation may provide a driving force for fluid migration. Calcareous sediments and organic-rich shales provide suitable traps. The saline fluids themselves may constitute a resource for soluble metals such as lithium.

Rift tectonics as a source of heat do not yield high temperatures. Fluid temperatures of the order of $100^{\circ} \mathrm{C}$ to $300^{\circ} \mathrm{C}$ seem to be adequate for ore deposition, although higher temperatures may be more favorable for the uptake and transport of metals. Deposition of the metals results from Eh or pH changes and perhaps from simple cooling.

Recognition criteria for these sediment-hosted, stratabound deposits include: (1) evidence for the presence of metal-bearing brines; (2) evidence for the movement of these brines within the basin; (3) the presence of analogous deposits; (4) the presence of suitable conduits; (5) the presence of suitable host rocks to act as traps; and (6) evidence for the appropriate timing of fluid flow and the opening of appropriate conduits.

Improvement in our predictive capacity for the Precambrian deposits will require a much greater understanding of the individual basement blocks and their boundary conditions. This will require a concerted, coordinated effort of a broad spectrum of specialists: sedimentologists and volcanologists to sort out the depositional setting of the rocks; geochronologists to date the various events that have affected the rocks; structural geologists and metamorphic petrologists to sort out the tectonic history; geophysicists to read through the younger cover rocks; and field mapping at scales of $1: 24,000$ and larger in key areas.

Improved understanding of the history, composition, and buried configuration of the basins will aid the search for younger deposits, as has already been suggested for the deposits related to detachment systems and disseminated precious-metal deposits. Again, a concerted, broadly based program is needed to understand the structural and stratigraphic composition of the basins, the geochemical and thermal history, paleohydrology, and the relative timing of these various events.

\section{CONCLUSION}

Arizona will continue to have a mineral industry, but it is recognized that a broader mineral base would help buffer the boom-and-bust tradition of its individual commodities. Such a base should include the metals discussed in this workshop, and also the nonmetallic mineral industry. The geologic, geochemical, and geophysical understanding of the resources in the state need to be expanded if the mineral industry is to remain capable of meeting the largely unknown needs of tomorrow's society. To that end, a broad research program is highly desirable. A successful program at the present state of the art and economy is likely to require the pooled resources of federal, state, and academic earth scientists. This will be necessary to obtain not only the physical resources but also the broad range of talents necessary to solve the complex problems envisioned.

A diverse audience is seen for the products of such a research program. Principal among these will be the next generation of exploration geologists who will require the expanded research base to locate and evaluate the next round of mineral discoveries. The need for additional resource information and predictive capabilities is also required to assess land use alternatives. The Bureau of Land 
Management and the U.S. Forest Service face these decisions immediately, and in many instances will have to assess the mineral potential of the public lands with only a partial data base. The Arizona State Land Department has similar needs to evaluate requests for metallic and nonmetallic mineral leases on state land. These agencies note the large gaps in the information base for the state. At the other end of the spectrum, federal and state legislators need answers to formulate public policy where mineral issues are involved or may be impacted. Thus, not only is additional information needed but it must be couched in terms suitable to the needs of a broad audience.

Many, perhaps most, of the mineral "discoveries" in Arizona have come from re-evaluation of known mineral districts. Ongoing studies of these districts must be encouraged, if for no other reason than to establish the models against which new search technologies can be compared. The State Geological Survey and the U.S. Bureau of Mines maintain information on the identified resources, and the universities and the U.S. Geological Survey have a continuing commitment to topical studies within the known districts. A broadly based research program will have to invest in district studies incident to that program, and, where the program has geographic boundaries, may require some transgression of those boundaries.

A commodity emphasis was also considered. Gold is currently a popular topic as are the strategic and critical minerals during periods of international unrest. The Bureau of Mines and the geological surveys maintain a cadre of specialists in individual commodities. The appropriate specialists should be consulted or be an active part of the research program.

\section{RECOMMENDATIONS}

Four broad areas of research offer possibilities for exciting breakthroughs that are virtually certain to produce significant use in future mineral exploration. Three of these could be initiated within a single, relatively restricted geographic area. The recommendations for key research studies are:

\section{A comprehensive study of the transition zone between the Colorado Plateau and the}

Basin and Range Province. This zone offers the best opportunity to study the major Proterozoic continental blocks that are the hosts for ore deposits and that have influenced later ore types. In this zone the transition occurs from the more passive ore types of the Plateau, exemplified by the collapse breccia pipes and the more dynamic ore-forming processes like those associated with detachment systems.

2. Systematic study of the genesis and geochemical character of the specialized granites. The products of extreme differentiation of these granites provide the most likely sources for ores of a critical suite of elements including niobium, tantalum, tin, tungsten, and molybdenum. Such a study should include examples of a variety of ages, Proterozoic to late Tertiary, and at a variety of levels of intrusion, plutonic to extrusive.

3. Comprehensive study of the middle to late Tertlary structure, stratigraphy, and volcanology. Such a study should emphasize the thermal regimes and paleohydrology. This is the environment in which ores associated with detachment systems, basins, and calderas are to be expected. 
4. The assembly, collation, and interpretation of currently scattered data on the geology, geochemistry, and geophysics of Arlzona. Such an effort, made possible by current data management systems, would identify such things as the major structural elements controlling the ore deposits of the state and the location and geometry of calderas and cauldrons.

These four broad areas of research are not mutually exclusive. Considerable overlap exists both from the topical standpoint and in the nature of the talent and approaches that would be employed. It is not surprising, therefore, that the first three could all be initiated within the Prescott $2^{\circ}$ sheet, a geographic area given high priority for comprehensive study. 


\section{LIST OF PARTICIPANTS}

Arizona Department of Mines and Mineral Resources

Mike Greeley

Arizona Geological Society

Joe Wilkins

Arizona Geological Survey, Tucson, AZ

Larry Fellows

John Spencer

John Welty

Arizona State Land Department, Phoenix, AZ

Ed Spalding

Arizona State University, Tempe, $A Z$

Donald M. Burt

Michael Sheridan

Northern Arizona University, Flagstaff, AZ

Karl Karlstrom

Paul Morgan

University of Arizona, Tucson, AZ

William R. Dickinson

John M. Guilbert

Joaquin Ruiz

Spencer R. Titley

U.S. Bureau of Land Management, Phoenix, AZ $\underline{\text { U.S. Bureau of Mines, Denver, CO }}$

Uldis Jansons

U.S. Geological Survey, Denver, CO

Byron Berger

Maurice Chaffee

Ed DeWitt

Bob Earhart

Doug Klein

lan Ridley

Bruce Smith

Paul Theobald

Karen Wenrich

U.S. Geological Survey, Flagstaff, AZ

Clay M. Conway

Gordon Haxel

U.S. Geological Survey, Menlo Park, CA

Dennis Cox

U.S. Geological Survey, Reston, VA

Glenn H. Allcott

Rob Robinson

U.S. Geological Survey, Tucson, AZ

Fred Robertson

Alan Rabinoff 